\title{
Wave-current interaction during Hudhud cyclone in the Bay of Bengal
}

\author{
Volvaiker Samiksha ${ }^{1}$, Ponnumony Vethamony ${ }^{1}$, Charls Antony ${ }^{1}$, Prasad Bhaskaran $^{2}$, and Balakrishnan Nair $^{3}$ \\ ${ }^{1}$ Physical Oceanography Division, CSIR National Institute of Oceanography, Dona Paula, Goa, 403004, India \\ ${ }^{2}$ Department of Ocean Engineering and Naval Architecture, Indian Institute of Technology Kharagpur, \\ Kharagpur, 721 302, India \\ ${ }^{3}$ Indian National Centre for Ocean Information Services, Hyderabad, 500 090, India \\ Correspondence to: Volvaiker Samiksha (vsamiksha@nio.org)
}

Received: 6 January 2017 - Discussion started: 7 April 2017

Revised: 19 October 2017 - Accepted: 21 October 2017 - Published: 29 November 2017

\begin{abstract}
The present work describes the interaction between waves and currents utilizing a coupled ADCIRC+SWAN model for the very severe cyclonic storm Hudhud, which made landfall at Visakhapatnam on the east coast of India in October 2014. Model-computed wave and surge heights were validated with measurements near the landfall point. The Holland model reproduced the maximum wind speed of $\approx 54 \mathrm{~m} \mathrm{~s}^{-1}$ with the minimum pressure of $950 \mathrm{hPa}$. The modelled maximum surge of $1.2 \mathrm{~m}$ matches with the maximum surge of $1.4 \mathrm{~m}$ measured off Visakhapatnam. The two-way coupling with SWAN showed that waves contributed $\approx 0.25 \mathrm{~m}$ to the total water level during the Hudhud event. At the landfall point near Visakhapatnam, the East India Coastal Current speed increased from 0.5 to $1.8 \mathrm{~m} \mathrm{~s}^{-1}$ for a short duration $(\approx 6 \mathrm{~h})$ with net flow towards the south, and thereafter reversed towards the north. An increase of $\approx 0.2 \mathrm{~m}$ in $H_{\mathrm{s}}$ was observed with the inclusion of model currents. It was also observed that when waves travelled perpendicular to the coast after crossing the shelf area, with current towards the southwest, wave heights were reduced due to wave-current interaction; however, an increase in wave height was observed on the left side of the track, when waves and currents opposed each other.
\end{abstract}

\section{Introduction}

In coastal and shelf regions, winds and waves interact with the prevailing current system and several mutual non-linear interactions occur. Studies (Kudryavtsev et al., 1999; Davies and Lawrence, 1995; McWilliams et al., 2004) show that waves contribute to local currents, water level and mixing. Wind- and wave-induced currents can reinforce or interfere with tidal currents, depending on the phase of the tide. The impact of surface waves on currents or currents on waves is an important aspect in coastal hydrodynamics. Several studies have been carried out relating to individual processes but not to interactions between them. Therefore, we need to take into account different processes that impact a specific process.

In the last few decades, there have been several efforts to develop theories and models on wave-current interactions (Ardhuin et al., 2008; Mellor, 2008; Warner et al., 2008; Uchiyama et al., 2010; Bennis et al., 2011). Holthuijsen and Tolman (1991) and Komen et al. (1994) studied interaction between current and wave fields in the regions of the Gulf Stream, the Kuroshio and the Agulhas currents. The refraction theory of waves on current has advanced well, and this concept has been already introduced into the waveaction conservation equation. Linear wave theory of vertically sheared weak current is also discussed using both perturbation and numerical methods (Kirby and and TsungMuh, 1989; Dong and Kirby, 2012). When waves propagate through strong currents, their characteristics change with refraction, bottom friction and blocking (Kudryavtsev et al., 1999; Ris et al., 1999). Also, the mean flow will be affected by the addition of momentum and mass fluxes. With variation in water level, the depth felt by the waves also changes in the coastal region, thereby modifying the shallow water effects on the waves (Pleskachevsky et al., 2009). Liu et al. (2016) 
investigated the non-linear wave-current interaction in water of finite depth analytically using the homotopy analysis method with solutions that are suitable for steep waves and strong currents expected during cyclonic conditions. The results were verified with flume experiments, and the analytical solution was in good agreement with experimental results. Various parameters such as influence of water depth, wave steepness and current velocity on co-existing wave-current field were also reported in the above study.

Some of the wave processes that impact the coastal environment are as follows: (i) wave set-up during cyclones, which contributes significantly to storm surge and inundation; for example, when waves were included in the model, Beardsley et al. (2013) found that more areas were influenced by flooding in the Massachusetts Bay. (ii) Wave-current interaction increases the bottom friction, thereby increasing the bottom stress. For example, Xie et al. (2001, 2003) introduced wave-induced surface and bottom stresses in the dynamic coupling between waves and currents. (iii) Carniel et al. (2009) and Zhang et al. (2011) included mixing due to wave breaking in their respective models and found improvements in the accuracy of surface drifter tracks in the Adriatic Sea and surface boundary layer thickness in the Yellow Sea. (iv) Mellor (2003) and Xia et al. (2004) incorporated radiation stress in the coupling between wave, ocean circulation and storm surge modelling.

Several numerical coupling experiments linking waves, currents and storm surges have been conducted in coastal areas in the past. For example, Tolman (1991) demonstrated the effect of water level and storm surges on wind waves for storms generated in the North Sea and indicated that storm surges are essential factors to be considered for assessing the wave-current interactions. Mastenbroek et al. (1993) and Zhang and Li (1996) modelled the impact of waves on storm surges and showed that wind stress with wavedependant parameterization amplified the storm surge by 10 $20 \%$. Moon (2005) developed a wave-tide-circulation coupled system by including the influence of wave-current interaction, wave breaking and depth changes due to water level and found that the wave-dependent stress is strongly dependent on wave age and relative position from the storm centre. However, it may be noted that storm surge, tides or oceanic currents will have a significant effect on wave field only if their strengths are sufficient to interact.

Presently, in storm surge modelling, circulation and wave models are coupled in the same mesh so that mesh resolution is fit to capture both circulation and wave physics. ADCIRC+SWAN (ADvanced CIRCulation+Simulating WAves Nearshore) is a coupled model that works on an unstructured mesh and allows for interaction between storm surges, waves and currents. This modelling system has been applied to hindcast hurricanes such as Katrina, Rita, Gustav and Ike (Westerink et al., 2008; Dietrich et al., 2011a, b, 2012; Hope et al., 2013; Longley, 2013; Sebastian et al., 2014).
Several studies (Rao et al., 1982; Murty et al., 1986; Dube et al., 1997, 2000; Rao et al., 2013b) reported storm surge along the east coast of India. Rao et al. (2013a) simulated surge and inundation using ADCIRC for the following cyclones: Kavali (1989), Andhra (1996) and Cuddalore (2000). Three super cyclones - 1999 Odisha cyclone, 2013 Phailin and 2014 Hudhud - created significant impact along the east coast of India (ECI). Phailin cyclonegenerated waves with significant wave heights of the order of $7 \mathrm{~m}$ (Balakrishnan et al., 2014). Hudhud was the first cyclone which effected urban areas and it is the second severe cyclone which crossed the Visakhapatnam coast (Amarendra et al., 2015). Also, the beach erosion was very severe on Ramkrishna beach, with a net sand volume of about $1457 \mathrm{~m}^{3}$ lost over a stretch of $14 \mathrm{~km}$ (Hani et al., 2015). From the literature review, it is evident that most of the storm surge studies carried out for the Indian coast used stand-alone models (Rao et al., 2013a; Bhaskaran et al., 2014; Gayathri et al., 2015, 2016; Dhana Lakshmi et al., 2017). A comprehensive review on the coastal inundation research and an overview of the processes for the Indian coast was reported by Gayathri et al. (2017). One can find very few studies reported using a coupled model (ADCIRC with SWAN) for the Indian seas (Bhaskaran et al., 2013; Murty et al., 2014, 2016; Poulose et al., 2017) for extreme weather events. These studies examined the performance of coupled models and role of improved wind forcing on waves and hydrodynamic conditions. The coupled model (ADCIRC+SWAN) has demonstrated its efficacy in predicting storm surge and water level elevation as compared to the stand-alone ADCIRC model. For example, the difference in residual water level at Paradeep obtained by stand-alone and coupled models at Paradeep in Odisha coast during 2013 Phailin cyclone were about $0.3 \mathrm{~m}$, and the coupled model performed relatively better than the stand-alone model (Murty et al., 2014). For the 2011 Thane cyclone good performance of coupled parallel ADCIRC+SWAN model was also reported by Bhaskaran et al. (2013). The model values of waves and currents obtained during Thane cyclone validated against high-frequency radar observations, satellite data of ENVISAT, JASON-1 and JASON-2, and wave rider buoy observations very clearly show that coupled model performed reasonably well. During extreme weather events like cyclones, the interaction between waves and currents is a highly non-linear process, and the transfer and exchange of energy between them is a very complex process. Along the nearshore region, the non-linear interaction process is highly complex and, to a larger extent, it is controlled by the local water depth and coastal geomorphological features. There can be instances, wherein the computed results using a coupled model may be underestimated, when the influence of currents is considered. However, in this case the role of bottom characteristics and water level needs a separate detailed study.

The present study is a comprehensive exercise that aims to study the following interactions during the Hudhud event: 
(i) impact of wave-current interaction on water level, (ii) impact of wave-current interaction on waves and (iii) impact of wave-current interaction on currents. This involves simulation of winds, tides, storm surges, currents and waves in the study domain during this extreme weather event using the coupled ADCIRC and SWAN models. Only wave and water level measured data were available for the verification of model results. Unfortunately, no measured current data were available for verification of the model-computed currents.

\section{Data and methodology}

\subsection{Modelling system}

ADCIRC and SWAN models were run in stand-alone and coupled modes on the same computational grid system. The cyclonic wind data were derived from the Holland formulation (Holland, 1980) using the best track estimate of Hudhud obtained from the Joint Typhoon Warning Center database. The hydrodynamic depth-averaged model ADCIRC applies the continuous Galerkin finite-element method to solve shallow water equations for water levels and vertically integrated momentum equations for velocity (Kolar et al., 1994; Atkinson et al., 2004; Luettich and Westerink, 2004; Dawson et al., 2006; Westerink et al., 2008; Kubatko et al., 2009; Tanaka et al., 2011). The model utilizes an unstructured mesh and allows for refinement in areas where the solution gradients are the highest. It has an option for wetting and drying that activates and deactivates the entire grid elements during inundation and recession.

SWAN is a third-generation wave model developed at the Delft University of Technology, Netherlands. It computes random, short-crested wind-generated waves in coastal regions and inland waters (Booij et al., 1999). The current version of SWAN is 40.85 (Zijlema, 2010). The model is based on the wave-action balance equation, with various source and sink mechanisms, that governs the redistribution of energy balance in the wave system. SWAN can be used on any scale relevant for wind-generated surface gravity waves. However, the SWAN model is specifically designed for coastal applications that should actually not require such flexibility in scale. The input parameters provided to SWAN includes bathymetry, current, water level, bottom friction and wind. The wave-action balance equation is expressed in the following form:

$$
\frac{\partial N}{\partial t}+\frac{\partial C_{g, x} N}{\partial x}+\frac{\partial C_{g, y} N}{\partial y}+\frac{\partial C_{g, \sigma} N}{\partial \sigma}+\frac{\partial C_{g, \theta} N}{\partial \theta}=\frac{S}{\sigma},
$$

where $N$ is the wave-action density, $\sigma$ is the relative frequency, $\theta$ is the wave direction, $C_{g}$ is the propagation speed in $(x, y, \sigma, \theta)$ space and $S$ is the total of source-sink terms expressed as the wave energy density. In SWAN model, the source terms are expressed in the following form:

$S=S_{\mathrm{in}}+S_{\mathrm{ds}, \mathrm{w}}+S_{\mathrm{ds}, \mathrm{b}}+S_{\mathrm{nl} 4}+S_{\mathrm{nl} 3}$.
The terms on the right-hand side of the equation represent wind input, white-capping, bottom friction, quadruplet wave-wave interactions and triad wave-wave interactions, respectively. The terms like bottom friction and triad wavewave interaction can be neglected in deep water calculations. The model coupling is based on the work of Bunya et al. (2010) and Dietrich et al. (2011b) conducted for the Gulf of Mexico region. The SWAN model employs an implicit sweeping method to update the wave field at each computational vertex, which allows SWAN to apply longer time steps than ADCIRC. Thus, the SWAN time step usually defines the coupling interval between SWAN and ADCIRC models (Dietrich et al., 2010, 2011a, b). The wind field during Hudhud cyclone was generated using the Holland parametric model, which is specifically meant for simulating winds during cyclones.

The tide data were taken from the Permanent Service for Mean Sea Level (PSMSL) (www.psmsl.org). Wave data were obtained from the directional wave rider buoy deployed off Visakhapatnam $\left(17.63^{\circ} \mathrm{N}, 83.26^{\circ} \mathrm{E}\right)$ at $15 \mathrm{~m}$ water depth. The measurement range is -20 to $20 \mathrm{~m}$, with an accuracy of $3 \%$. The in situ data were recorded continuously at $1.28 \mathrm{~Hz}$, and the recording interval for every $30 \mathrm{~min}$ was processed as one record. At every $200 \mathrm{~s}$, a total number of 256 heave samples were collected and a fast Fourier transform was applied to obtain a spectrum in the frequency range of 0 to $0.58 \mathrm{~Hz}$ with a resolution of $0.005 \mathrm{~Hz}$. Eight consecutive spectra covering $1600 \mathrm{~s}$ were averaged and used to compute the half-hourly wave spectrum. Significant wave height $\left(H_{\mathrm{s}}\right)$ or $4 \sqrt{m_{0}}$ was obtained from the wave spectrum. The $n$ thorder spectral moment $\left(m_{n}\right)$ is given by $m_{n}=\int_{0}^{\infty} f^{n} S(f) \mathrm{d} f$, where $S(f)$ is the spectral energy density at frequency $f$. The period corresponding to the maximum spectral energy (i.e. spectral peak period, $T_{\mathrm{p}}$ ) was estimated from the wave spectrum. The wave direction $\left(D_{\mathrm{p}}\right)$ and directional width corresponding to the spectral peak were estimated based on the circular moments (Kuik et al., 1988).

\subsection{Model domain and set-up}

The model domain, chosen for the generation of winds, waves, currents and storm surges, covers the entire Bay of Bengal from 80 to $98^{\circ} \mathrm{E}$ and 6 to $21^{\circ} \mathrm{N}$ (Fig. 1a). The modified Etopo2 datasets by Sindhu et al. (2007) were used to generate the bathymetry grid. The data include improved shelf bathymetry for the Indian Ocean derived from sounding depths less than $200 \mathrm{~m}$ from the charts of the Naval Hydrographic Office in India. The triangulated irregular mesh was prepared using SMS (Surface-water Modeling System, http://www.aquaveo.com/) package for the selected domain (Fig. 1b). The unstructured mesh resolves sharp gradients in bathymetry, particularly in nearshore regions (Dietrich et al., 2011b), and it minimizes the computational cost relative to a structured mesh. For better results, tides and surges are re- 
(a)

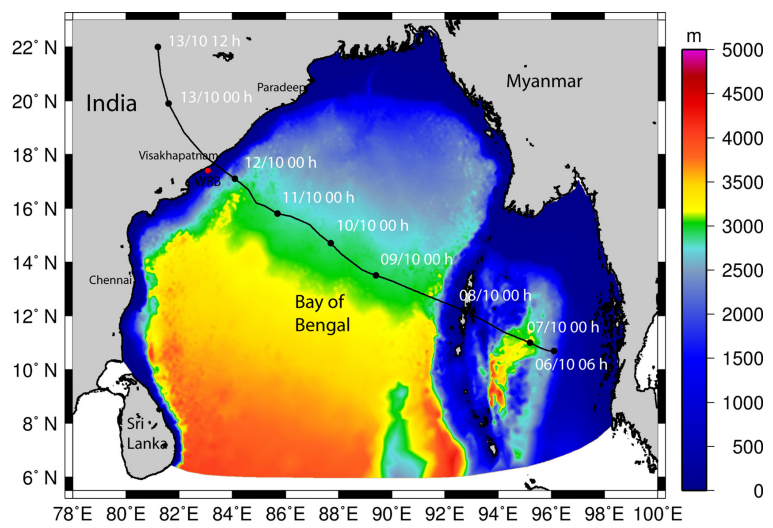

(b)

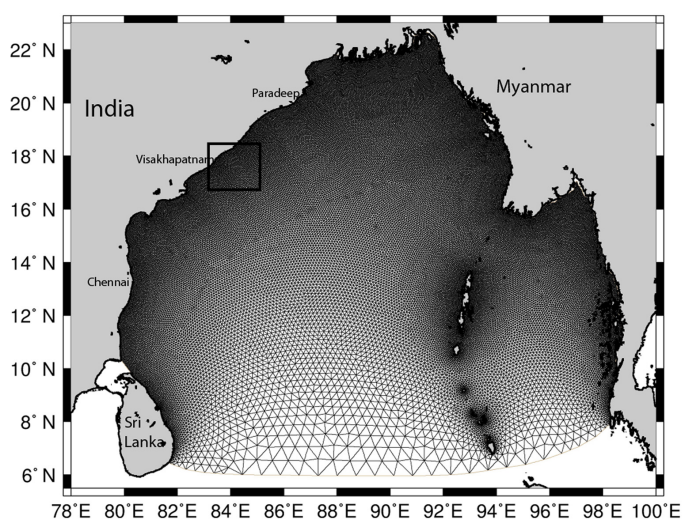

(c)

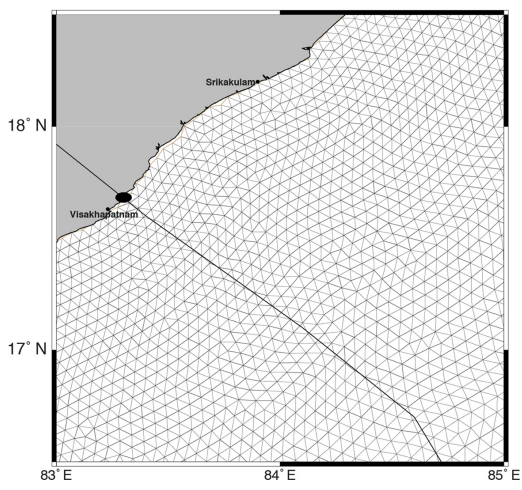

Figure 1. (a) Bathymetry of the model domain chosen for wavecurrent interaction during Hudhud cyclone; cyclone track details are shown, and the red dot represents the wave rider buoy location. (b) Fine-resolution unstructured mesh generated for the domain to run the coupled ADCIRC+SWAN model; rectangular box represents the region where measured data are available for model validation (details of the box is shown in c). (c) Fine-resolution mesh of the box shown in (b); black circle is the landfall point of the Hudhud cyclone, and the cyclone track is also shown.

solved using a coarse grid in deep water and higher resolution in the nearshore (Blain et al., 1994; Luettich and Westerink, 1995). Accordingly, in the present study, the mesh was generated with 82253 elements and 41795 nodes (Fig. 1b). A zoomed-in view of the landfall region with fine resolution of the mesh is shown in Fig. 1c. The mesh resolu- tion varies from $1 \mathrm{~km}$ in the nearshore region to a maximum of $80 \mathrm{~km}$ in the deep water. The model has been run in a twodimensional depth-averaged mode. The specifications of the model set-up are (i) spherical coordinate system for the domain, (ii) cyclone duration (6.75 days), (iii) constant bottom friction (0.0025), (iv) minimum depth of $0.5 \mathrm{~m}$ for wet and dry elements and (v) horizontal eddy viscosity coefficient of $2 \mathrm{~m}^{2} \mathrm{~s}^{-1}$.

The dynamic Holland wind field model (Holland, 1980) calculates the wind field, sea-level pressure distribution and gradient wind within the tropical cyclone. The wind stress was specified to ADCIRC model using the relation proposed by Garrett (1977). Figure 2 shows the relative position of cyclone eye and associated wind field of the Hudhud cyclone computed from the wind model at different intervals as the cyclone approached the coast, before making the landfall at Visakhapatnam coast. Holland model reproduced the maximum wind speed of $\approx 186 \mathrm{~km} \mathrm{~h}^{-1}$ with a minimum central pressure drop of $950 \mathrm{hPa}$ when it transformed into a very severe cyclonic storm.

\subsection{Model set-up for water level, current and wave generation}

ADCIRC was tightly coupled to the unstructured wave model SWAN (Zijlema, 2010). The ADCIRC model was cold started with 13 tidal harmonic constituents (K1, N2, O1, P1, S2, K2, L2, M2, 2N2, MU2, NU2, Q1 and T2) taken from the LeProvost tidal database, and specified along the open boundary to reproduce tidal response in the Bay of Bengal. In the present study, the unstructured version of SWAN (version 40.85) has been used, which implements the four-direction Gauss-Seidel iteration technique with unconditional stability (Zijlema, 2010). SWAN was discretized into 31 frequency bins ranging from 0.05 to $1.00 \mathrm{~Hz}$ on a logarithmic scale and 36 direction bins with an angular resolution of $10^{\circ}$. SWAN was set up with Cavaleri and Malanotte-Rizzoli (1981) wave growth physics; the shallow water triad nonlinear interaction was computed using the lumped triad approximation of Eldeberky (1996). Earlier studies (Bhaskaran et al., 2014; Gayathri et al., 2015, 2016, Dhana Lakshmi et al., 2017; Bhaskaran et al., 2013; Murty et al., 2014, 2016; Poulose et al., 2017), carried out using the formulation of Komen et al. (1984) for cyclones which occurred in the Indian Ocean region, showed that SWAN with this scheme performed well for extreme weather events. Keeping this in view, in the present study, we have used the same formulation of Komen et al. (1984) to study the wave-current interaction during the Hudhud event. The model was initiated with modified white-capping dissipation (Komen et al., 1984). Quadruplet non-linear wave-wave interaction was computed using discrete interaction approximation (Hasselmann et al., 1985) and depth-induced breaking was computed using spectral version of the model with breaking index of $\gamma=0.73$ (Battjes and Janssen, 1978), while bottom friction was calcu- 

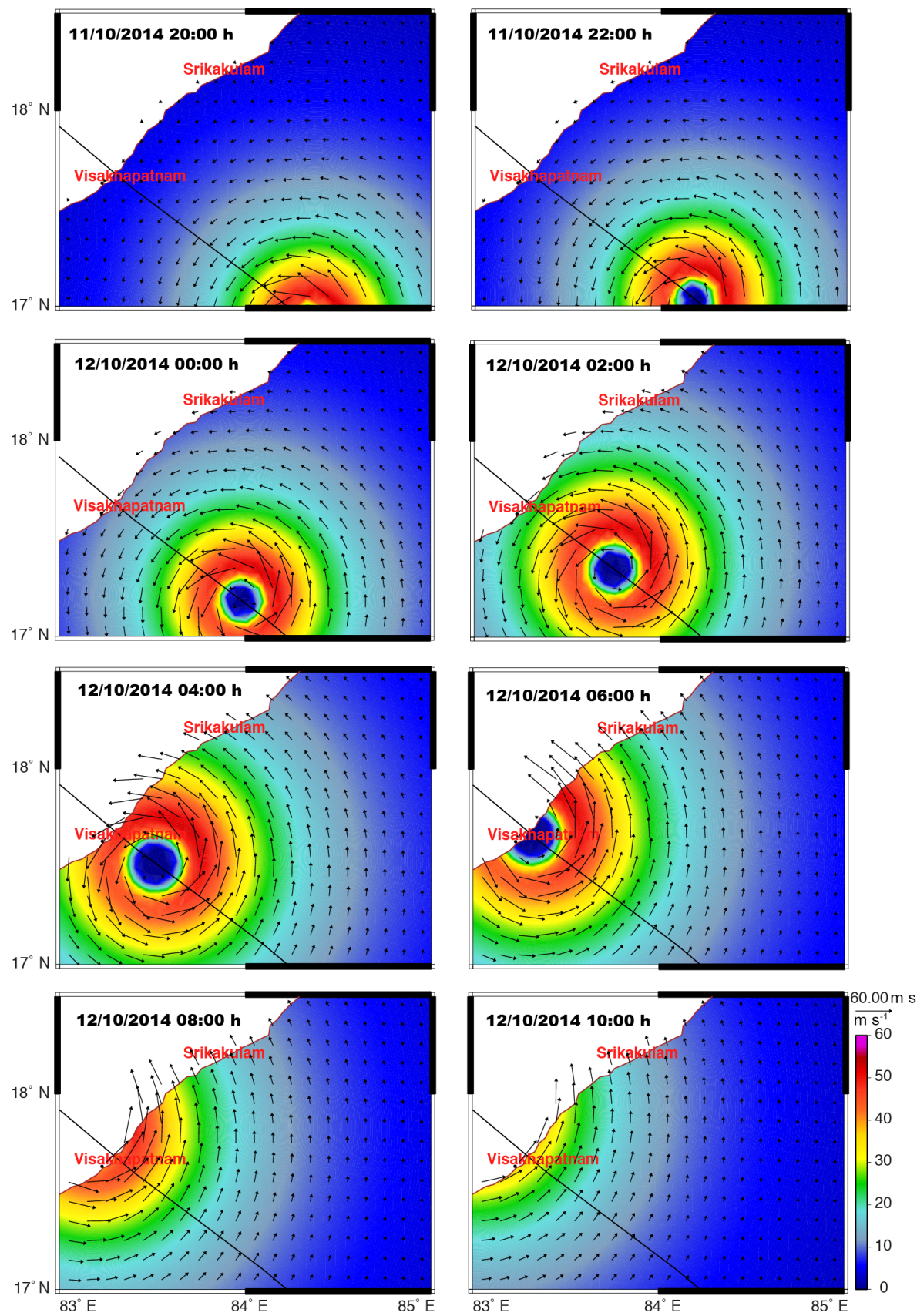

Figure 2. Typical winds (speed and direction) generated using Holland asymmetrical model along the track of the Hudhud cyclone (colour code represents wind speed in metres per second; vectors represent wind direction).

lated based on JONSWAP physics (Hasselmann et al., 1973) with a friction coefficient, $C_{b}=0.05 \mathrm{~m}^{2} \mathrm{~s}^{-3}$. ADCIRC time step was specified as $10 \mathrm{~s}$ and SWAN as $600 \mathrm{~s}$. After every time step of SWAN, two-way coupling was carried out.

The model coupling is based on the work of Bunya et al. (2010) and Dietrich et al. (2011b) in the Gulf of Mexico. SWAN employs an implicit sweeping method to update the wave details at each computational vertex, which allows SWAN to apply longer time steps than ADCIRC.
Thus, the SWAN time step usually defines the coupling interval between SWAN and ADCIRC models (Dietrich et al., 2010, 2011a, b). SWAN-computed radiation stress was passed on to ADCIRC to calculate wave set-up and nearshore currents. Similarly, water levels and currents computed by ADCIRC were passed on to SWAN in the prescribed time step. SWAN accesses these inputs and wind speeds at each node and time, corresponding to the beginning and end of present interval. The radiation stress gradi- 

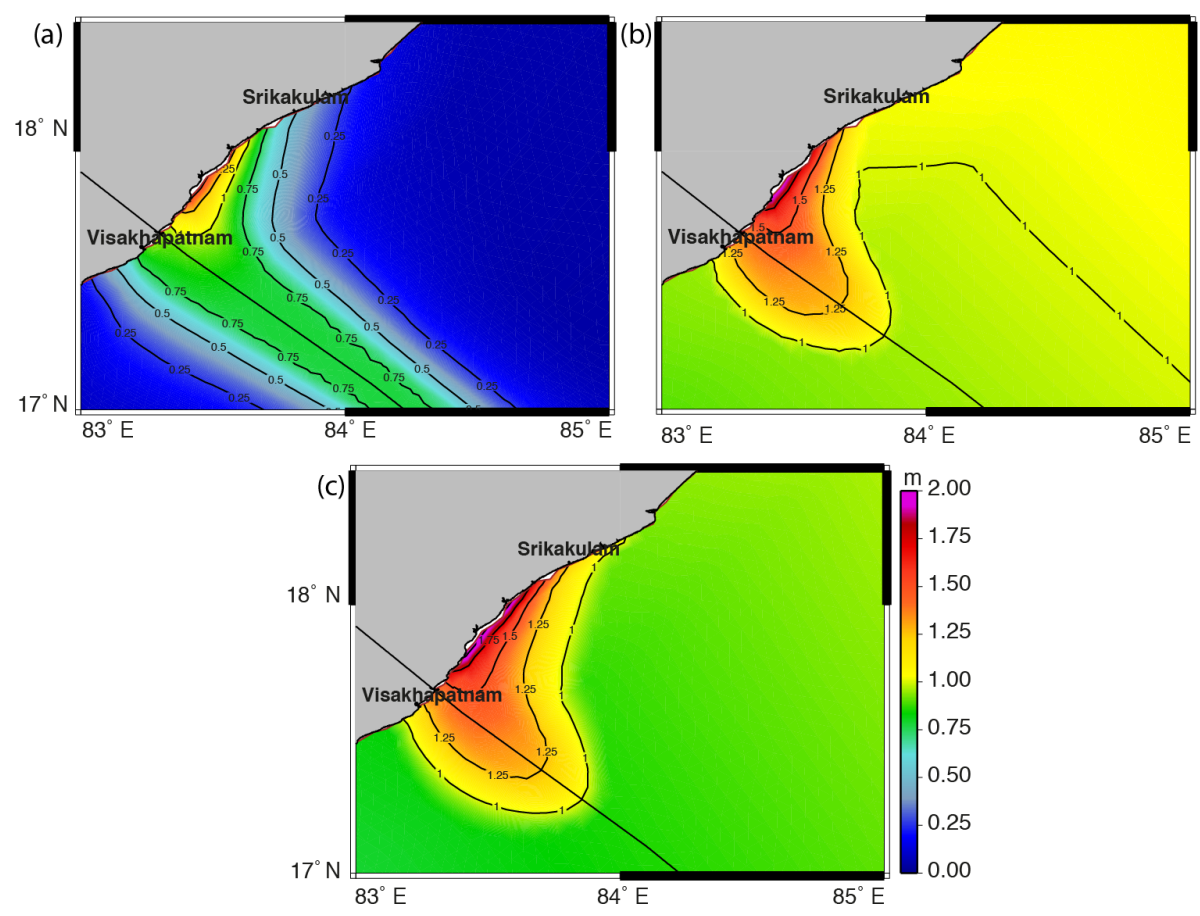

Figure 3. Spatial distribution of maximum surface elevation (metres) due to (a) cyclonic winds, (b) cyclonic winds and tides and (c) cyclonic winds, tides and waves (colour code represents surface elevation in metres).

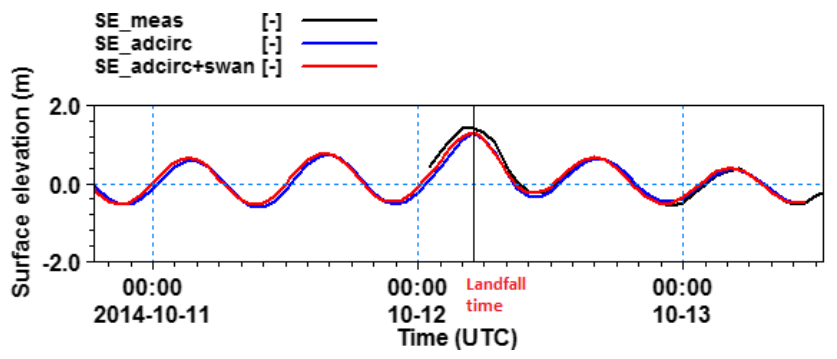

Figure 4. Time series of surface elevation (metres) representing measured surface elevation (red line), SE from ADCIRC alone (blue line) and SE from ADCIRC+SWAN (black line) at Visakhapatnam coast $\left(17.63^{\circ} \mathrm{N}, 83.26^{\circ} \mathrm{E}\right)$ during $10-13$ October 2014.

ents used by ADCIRC were extrapolated forward in time, while the wind speeds, water levels and currents used by SWAN were averaged over each time step.

\section{Results and discussion}

\subsection{Cyclone track and wind generation}

Hudhud cyclone is the second-strongest tropical cyclone that crossed Visakhapatnam after 1985 (Amarendra et al., 2015) and caused extensive damage to property. Hudhud crossed the Andaman Islands on 8 October 2014 at 09:30 h (IST). It moved west-northwest and intensified into a very severe cyclonic storm on 10 October 2014 (afternoon). It intensified further on 12 October and crossed the Visakhapatnam coast around 13:00 h (IST) with a maximum wind speed of $180 \mathrm{~km} \mathrm{~h}^{-1}$ (IMD Report, 2014). Figures 1a and 2 show the track and passage of Hudhud. The maximum wind speed reproduced by the Holland model is $\approx 54 \mathrm{~m} \mathrm{~s}^{-1}$ (Fig. 2) with maximum pressure drop to $950 \mathrm{hPa}$.

\subsection{Role of waves in surface elevation during Hudhud cyclone}

Tidal phase plays a major role in affecting the surface elevation during cyclones. If a cyclone makes its landfall during high tide, the effective water level would be higher than during low tide. In this case, the landfall of the Hudhud cyclone occurred during spring high tide. We have conducted three numerical experiments to assess the impact of waves, currents and tides on the total water surface elevation along the track during the passage of the Hudhud cyclone. In the first experiment, the ADCIRC model was set up with only the cyclonic winds and atmospheric pressure generated by the Holland asymmetrical model (Fig. 2), and tides were switched off. The model produced the maximum surge, which was due to cyclonic winds and pressure alone. In the second experiment, ADCIRC model was run with tides, cyclonic winds and atmospheric pressure, and the model provided the maximum water elevation generated by these contributing factors. The third experiment was a two-way coupling of ADCIRC 

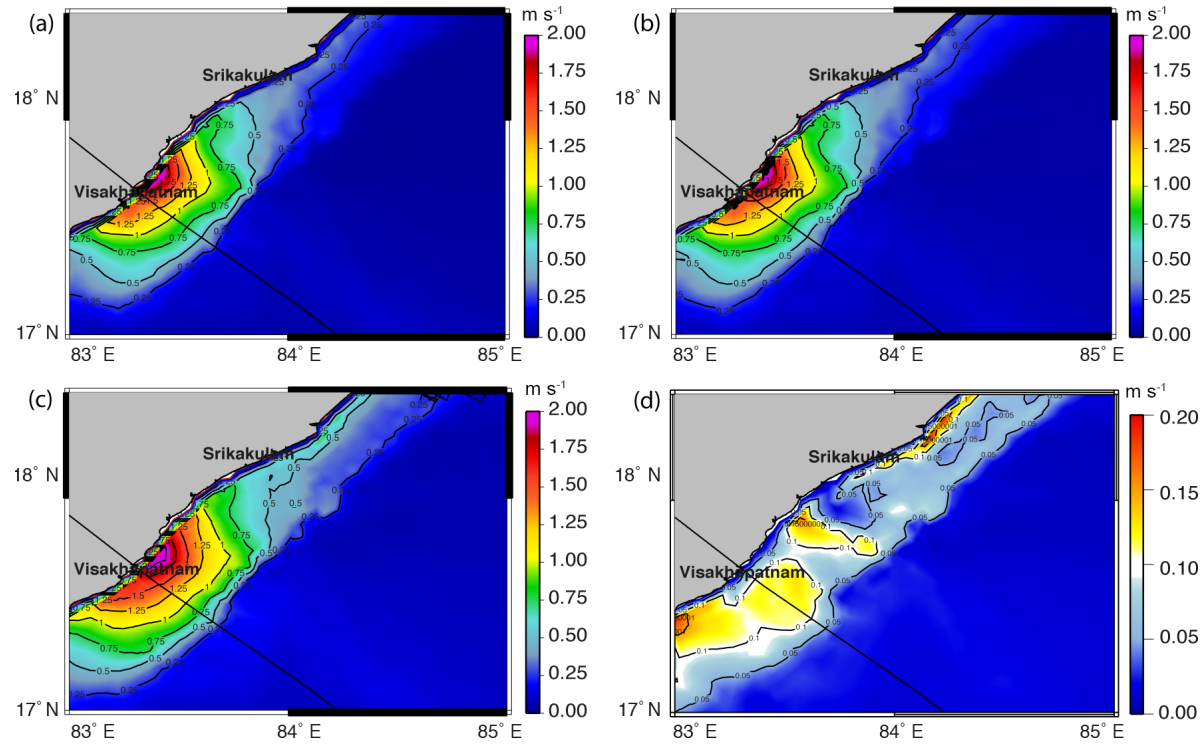

Figure 5. Spatial distribution of maximum surface currents (metres per second) due to (a) winds, (b) winds and tides and (c) winds, tides and waves during cyclone. (d) Difference in current speeds from (b) and (c), illustrating change in current speeds due to wave-current interaction (colour code represents current speeds in metres per second).

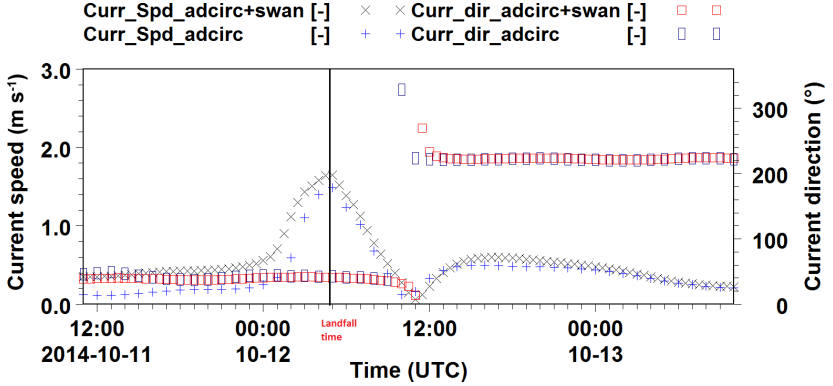

Figure 6. Time series of currents (metres per second) representing current speeds and direction obtained from ADCIRC alone (x and blue rectangle) and coupled ADCIRC + SWAN ( + and red rectangle) off Visakhapatnam coast $\left(17.63^{\circ} \mathrm{N}, 83.26^{\circ} \mathrm{E}\right)$ during $10-13$ October 2014.

and SWAN; that is, the model run was executed by combining winds, pressure fields, tides and wave forcing.

The resultant surface elevations from all these three numerical experiments were intercompared and also validated with tide gauge data off Visakhapatnam. The tide data from PSMSL were adjusted to a mean sea-level reference to match with ADCIRC-generated surface elevation. Figure 3 represents the spatial distribution of maximum water surface elevation (in the whole domain) produced by the cyclone from the above three experiments. The India Meteorological Department (IMD Report, 2014) reports a maximum water level of $1.6 \mathrm{~m}$. However, the tide gauge at Visakhapatnam recorded a maximum water level of $1.4 \mathrm{~m}$. The simulation with winds, tides and waves predicted a water level of $1.2 \mathrm{~m}$ (Fig. 4), which matches reasonably well with the measured data and other model predictions (with a difference of $0.2 \mathrm{~m}$ during peak surge).

The two-way coupling with SWAN showed an increment of $\approx 0.15 \mathrm{~m}$ in total water level near Visakhapatnam during the cyclone, which contributed by waves to the total rise in water level. Wave set-up along the coast was caused as a result of waves generated by the storm that subsequently released momentum (radiation stress; Longuett-Higgins and Stewart, 1964) to the water column due to dissipation. Therefore, during storm events, water level rises not only by winds, but by waves also, though the magnitude is much less compared to the water level contributed by the winds and pressure. Model results from both the runs were analysed to observe the change in storm surge height due to wave set-up along the storm affected coastal regions, and the maximum change in the modelled surge height was $\approx 0.25 \mathrm{~m}(\approx 20 \%$ of total surge height) between Visakhapatnam and Srikakulam (Fig. 3b, c). Overall, the model prediction showed that during the Hudhud cyclone, the wave-induced set-up had a significant impact on the total surge height, which provides an example of the importance of coupling wave and circulation model in predicting the total storm surge height accurately, especially during extreme tropical cyclones.

\subsection{Effect of wave-current interaction on currents}

Currents in the study region generated during the Hudhud cyclone period were analysed to study the impact of wavecurrent interaction on the local current system. The maximum current speed obtained from the three numerical experiments (model runs) are shown in Fig. 5. As current measurements were not available for the cyclone period, the model 

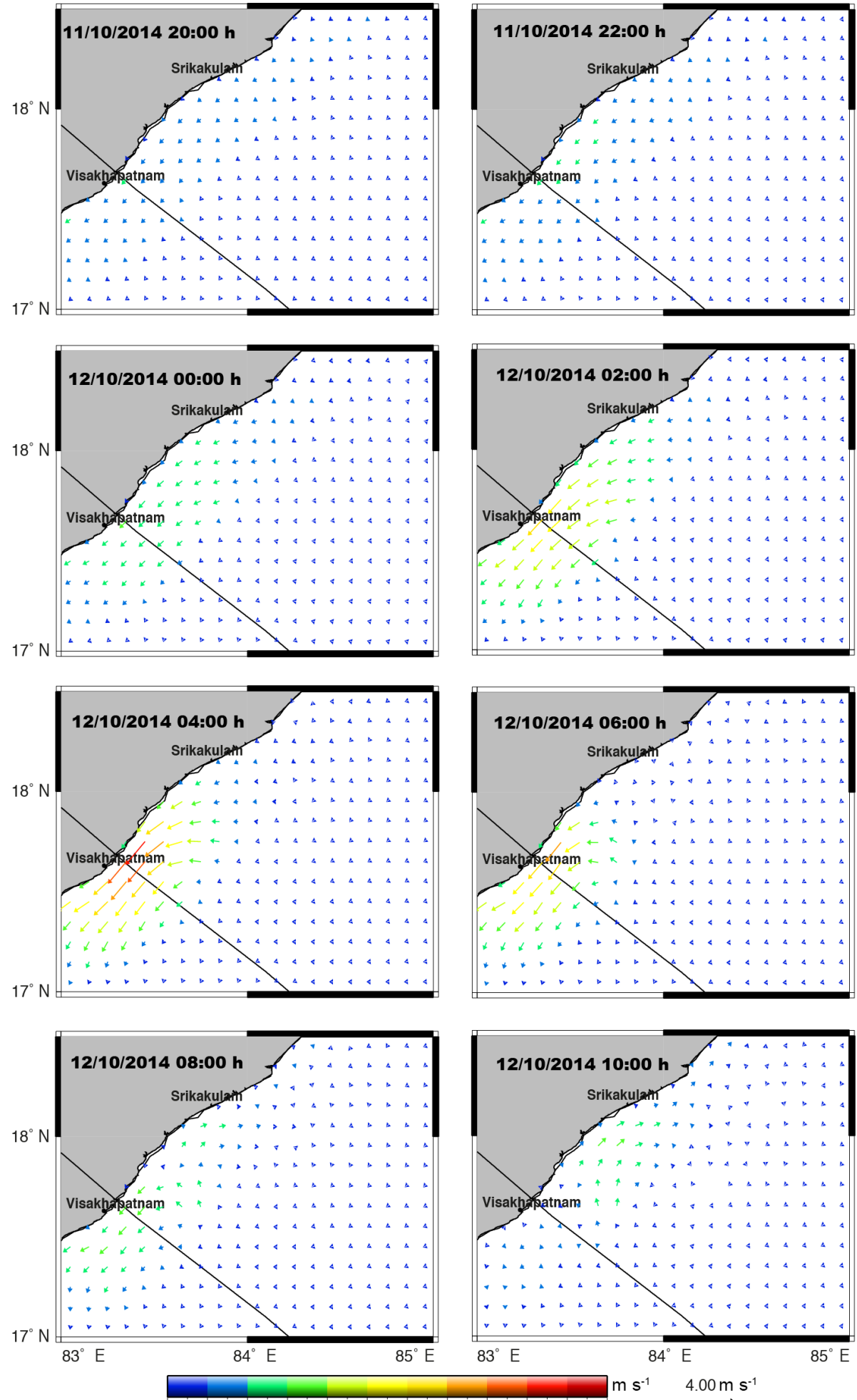

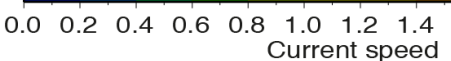

Figure 7. Current speed and direction simulated along the track of the Hudhud cyclone using the coupled ADCIRC + SWAN model (colour code represents current speed in metres per second; vectors represent current direction). 

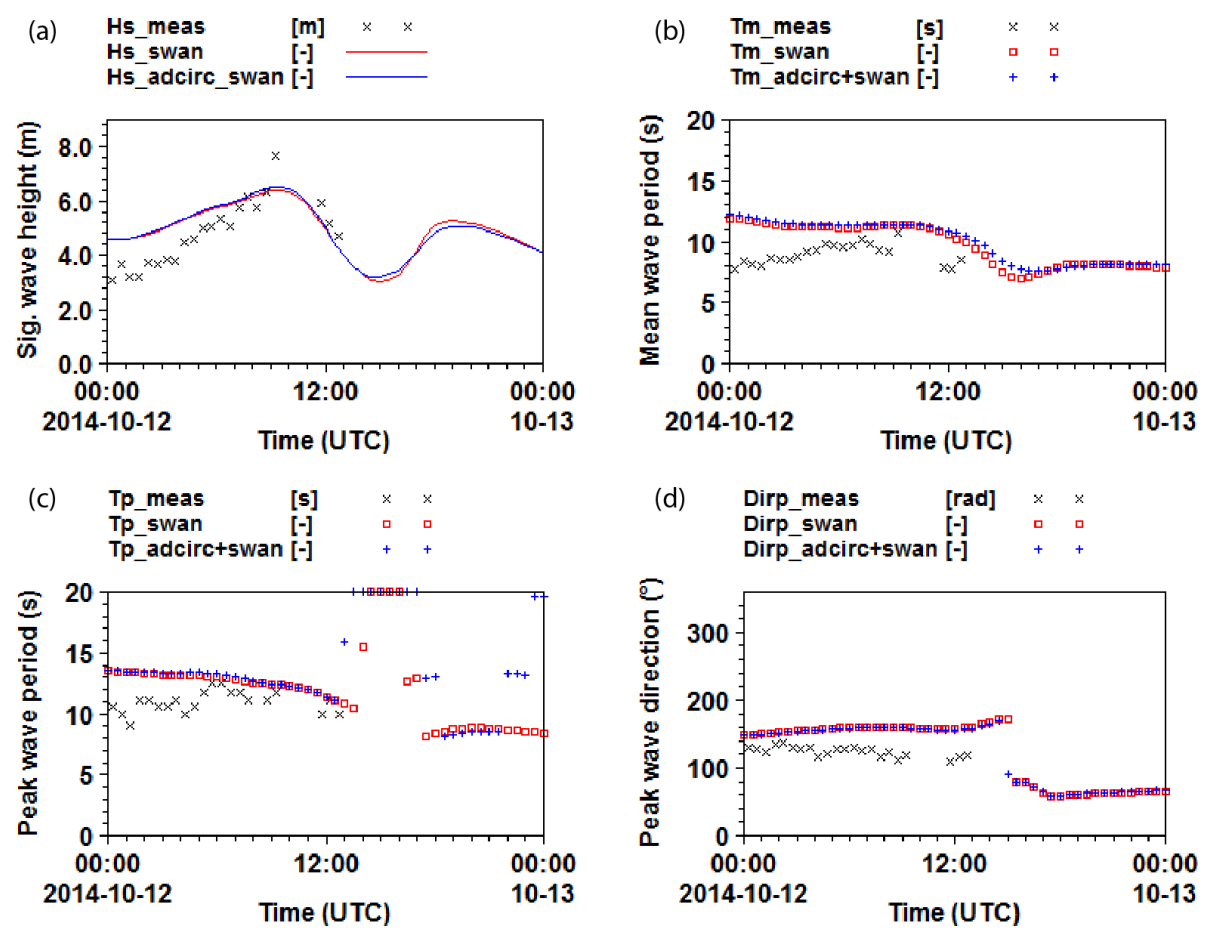

Figure 8. Comparison of measured (black) and modelled (a) significant wave heights $\left(H_{\mathrm{s}}\right)$, (b) mean wave periods, (c) peak wave periods and (d) peak wave directions obtained from SWAN (red) and coupled ADCIRC+SWAN (blue) during Hudhud cyclone with measured data off Visakhapatnam $\left(17.63^{\circ} \mathrm{N}, 83.26^{\circ} \mathrm{E}\right)$.

produced velocity fields were analyzer and compared with earlier studies. In general, the East India Coastal Current flows towards north along the ECI during southwest monsoon. During northeast monsoon, the current reverses and flows southward (Schott et al., 1994; Schott and McCreary, 2001; Shankar et al., 2002). On average, the maximum current speed along the ECI varies from 0.2 to $0.5 \mathrm{~m} \mathrm{~s}^{-1}$ (Mishra, 2010; Mishra, 2011; Panigrahi et al., 2010). Misra et al. (2013) observed through model simulations that tidal currents near the coast (water depth of $20 \mathrm{~m}$ ) increase gradually from south to north.

The present simulations predicted current speeds up to $0.5 \mathrm{~m} \mathrm{~s}^{-1}$, and this range is consistent with the earlier studies. However, during the cyclone period, the two-way coupling (ADCIRC+SWAN) increased the current magnitude by $0.25 \mathrm{~m} \mathrm{~s}^{-1}$ (due to waves) along the cyclone track and near the landfall region. When the cyclone made its landfall near Visakhapatnam, the current speed increased from 0.5 to $1.8 \mathrm{~m} \mathrm{~s}^{-1}$ for a short duration $(\approx 6 \mathrm{~h})$ with direction of flow towards south. After $\approx 6 \mathrm{~h}$ of landfall, current speed reduced to $\approx 0.1 \mathrm{~m} \mathrm{~s}^{-1}$, with reversal of current (towards north) (Figs. 6 and 7). The current pattern shows semidiurnal variation associated with tidal currents. The spatial distribution of current speed and direction during the cyclone period driven by winds, tides and waves is given in Fig. 7, and it is very evident how the flow pattern changed with the passage of cyclone.

\subsection{Effect of wave-current interaction on waves}

Waves were modelled using SWAN alone and SWAN coupled with the ADCIRC to assess the impact of currents on the cyclone-generated waves. Measured wave data were available only at one location, off Visakhapatnam $\left(83.26^{\circ} \mathrm{E}\right.$, $17.63^{\circ} \mathrm{N}$ ), which was on the track of the Hudhud cyclone. Figure 8 presents the comparison between the simulated and measured wave heights, wave periods and wave directions for the model runs of SWAN alone and coupled ADCIRC+SWAN. In the early stages of Hudhud, the wave heights were of the order of 3-5 m near the Andaman and Nicobar islands (Fig. 9). But, when Hudhud intensified further while progressing towards ECI, it generated waves with heights of the order of 9-11 m, before making the landfall near Visakhapatnam on 12 October 2014 (12:00 h). Figure 9 shows a swath of large waves (wave heights exceeding $10 \mathrm{~m}$ ) propagating towards the coast with the passage of the storm. When the system was examined just before the landfall on 11 October 2014 at 20:00 h (Fig. 9), it was found that the waves followed the pattern of cyclone winds. As waves experienced depth-limited breaking during its course onto the continental shelf, they propagated towards the right side of the cyclone track. Near Visakhapatnam, the buoy recorded a peak wave height of $7.8 \mathrm{~m}$ (Fig. 8), whereas the model peak value is $6.2 \mathrm{~m}$. Referring to Fig. 8, we find that more or less the measured significant wave heights match with 

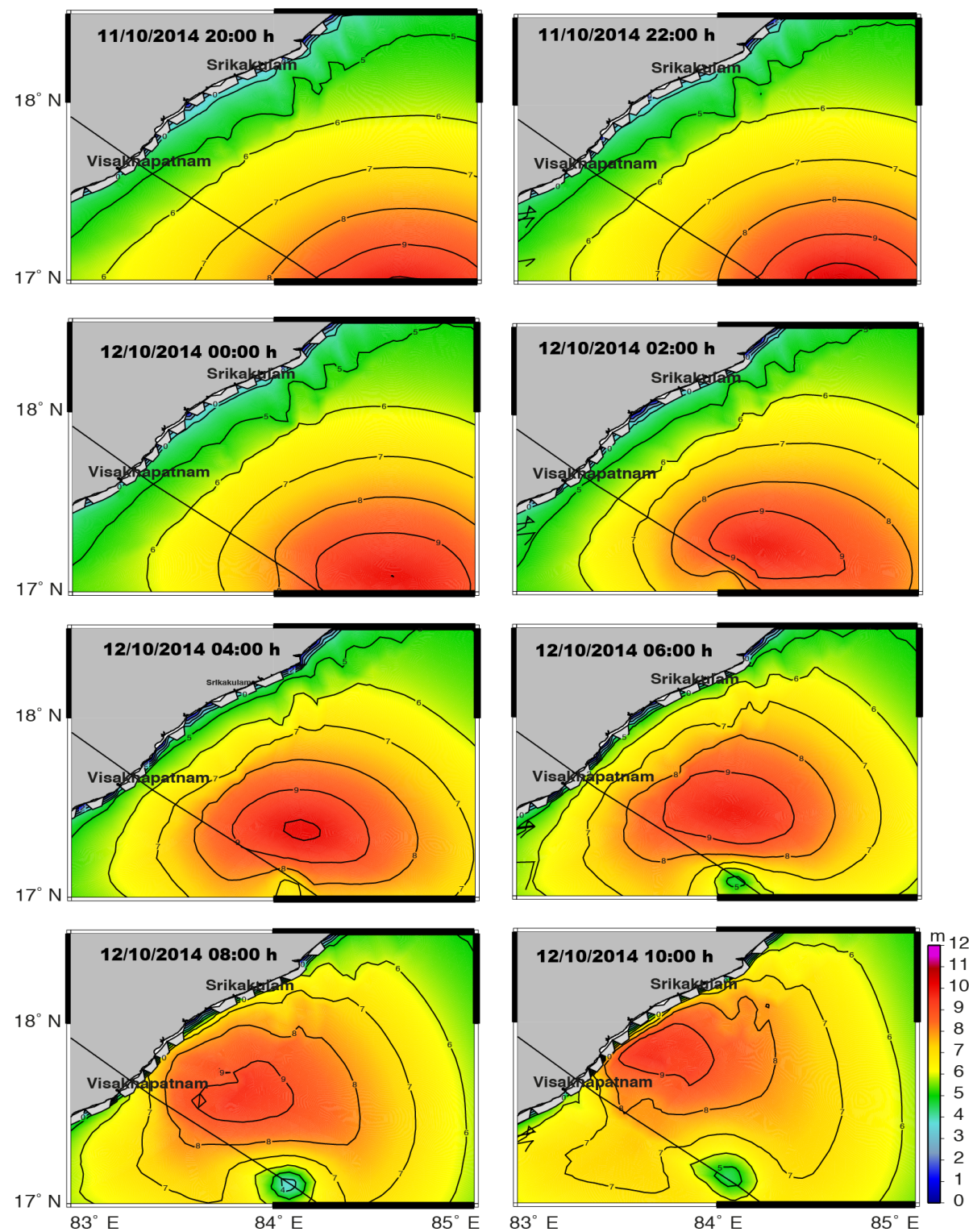

Figure 9. Significant wave heights $\left(H_{\mathrm{S}}\right)$ simulated along the track of the Hudhud cyclone using the coupled ADCIRC+SWAN model $($ colour contours represent $H_{\mathrm{S}}$ in metres).

the modelled wave heights (with and without currents near the buoy location, off Visakhapatnam). When current was introduced, wave heights reduced approximately by $0.2 \mathrm{~m}$ and mean wave periods reduced by $2 \mathrm{~s}$. It may be noted that during this time, the waves and currents were nearly in the same direction (Figs. 7 and 8d). Subsequently, when current speed increased to $0.5 \mathrm{~m} \mathrm{~s}^{-1}$ (Fig. 6) from 13:00 to 20:00 h (12 October 2014) with the wave and currents directions opposite to each other, we observe an increase in wave height of approximately $0.3 \mathrm{~m}$. Hence, there is an influence of currents on waves though it is marginal. The spatial distribution of maximum significant wave heights $\left(H_{\mathrm{S}}\right)$ simulated along the track of Hudhud cyclone using SWAN (no wave-current interac- tion) and coupled ADCIRC+SWAN (with wave-current interaction) is given in Fig. 10a and b. Figure 10c illustrates change in wave energy due to wave-current interaction. Table 1 highlights various statistical metrics with and without currents on the wave system at the buoy location for Hudhud. It is evident from Table 1 that inclusion of currents does not improve wave simulation for Hudhud cyclone. It is found that inclusion of currents deteriorated the wave simulation at the buoy location when waves and currents were nearly in the same direction, whereas, when waves and currents were in the opposite direction, the inclusion of currents enhanced the wave simulation. Overall, it is seen that the influence of currents on the wave system is marginal. This observation 

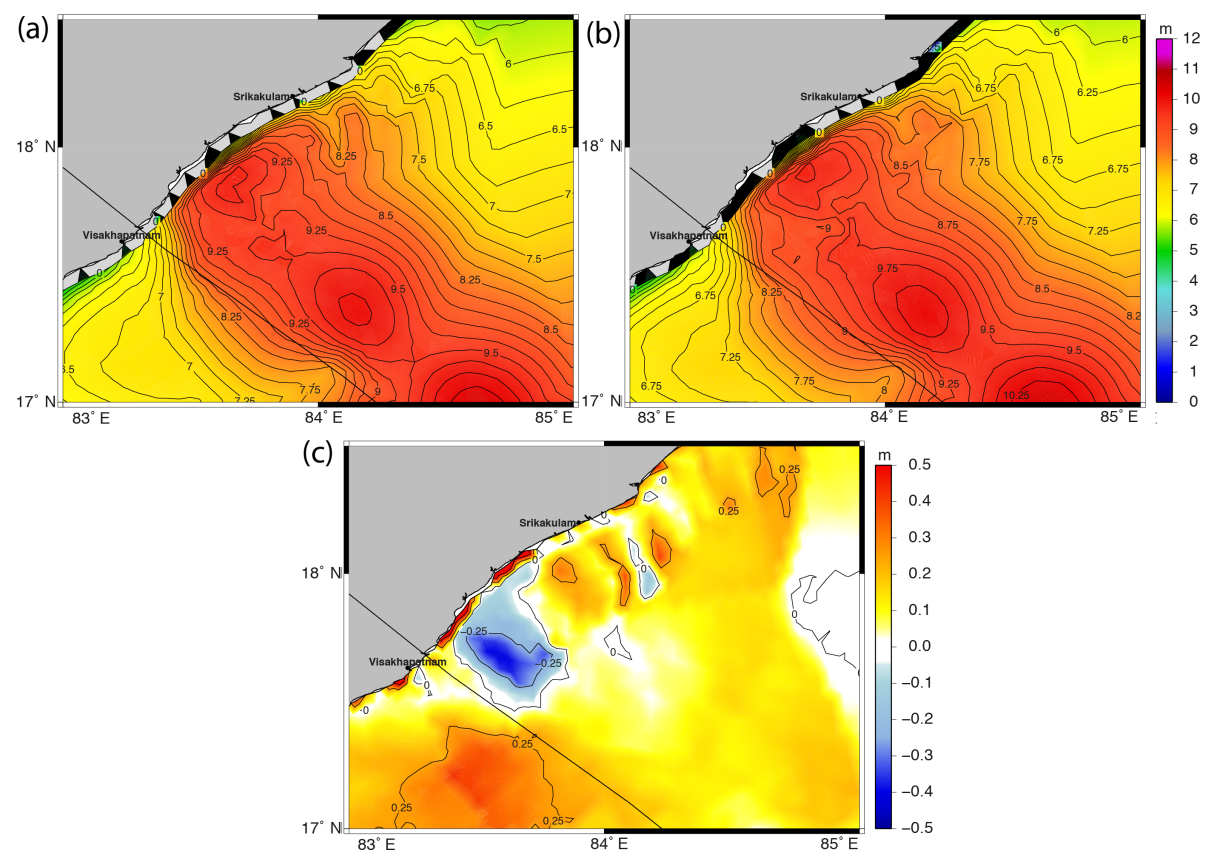

Figure 10. Spatial distribution of maximum significant wave heights $\left(H_{\mathrm{S}}\right)$ simulated along the track of the Hudhud cyclone using (a) SWAN model (no wave-current interaction) and (b) coupled ADCIRC+SWAN model (with wave-current interaction); the colour code and contours represent $\mathrm{H}_{\mathrm{s}}$. (c) Change in $H_{\mathrm{s}}$ from (a) and (b), illustrating change in wave energy due to wave-current interaction.

is also supported by the recent study of Liu et al. (2016). They stated that an opposing current can lead to significant decrease in wave length and thereby tends to narrow both the crest and trough of the wave. This in turn causes an increased elevation in wave crest as the opposing current speed increases, whereas the wave trough elevation tends to remain constant throughout. On the contrary, when waves and currents follow same direction, there is enhancement in wave length that tends to decrease the wave height elevation (Liu et al., 2016).

The spatial distribution of mean wave period $\left(T_{\mathrm{m}}\right)$ and peak wave period $\left(T_{\mathrm{p}}\right)$ simulated along the track of the Hudhud cyclone using coupled ADCIRC+SWAN model (with wave-current interaction) is presented in Fig. 11a and b. Figure $11 \mathrm{a}$ shows large mean wave periods $(\approx 13 \mathrm{~s})$ in the nearshore region off Visakhapatnam during the cyclone (otherwise, during normal condition, wave periods will be of the order of $6 \mathrm{~s}$ ). Figure $11 \mathrm{~b}$ shows small pockets (at a few locations) of waves with large peak periods, of the order of $20 \mathrm{~s}$, moving towards the coast, south of Visakhapatnam. It was found that despite these large peak periods, the coupled wave-surge modelling system reproduced reasonably good wave-induced water level changes at these locations. Bender et al. (2012) reported similar large peak period scenarios and reasoned that the ADCIRC model applies the SWAN radiation stress gradients based on individual spectral components only, and not the peak or mean parameters. This feature is also supported by the results of another coupled model, STWAVE, applied to the Louisiana storm surge (Atkinson et al., 2008), where isolated regions exhibited peak wave periods, greatly different from the surrounding values. Dietrich et al. (2013) presented a method that greatly removed the high peak period values with little degradation of model results. These isolated high peak wave periods point to the difficulty in simulating waves in inundating inland areas with shallow water depths and significant wind forcing.

Figure 12a presents the maximum radiation stress gradient values calculated from SWAN and passed on to the ADCIRC component of the coupled model. In the nearshore, the breaking waves exert stress on water column, causing changes in total water level and underlying currents. Figure 12a shows the expected features for radiation stress gradient of $0.009 \mathrm{~m}^{2} \mathrm{~s}$ in the main wave breaking zone along the coastline when Hudhud made landfall between Visakhapatnam and Srikakulam.

We find from Fig. 10c that wave heights reduced by $0.5 \mathrm{~m}$ on the right side of the cyclone. Figure $12 \mathrm{~b}$ shows that waves travelled perpendicular to the coast after crossing the shelf area and currents flowed in the southwest direction (Fig. 7), and due to wave-current interaction wave heights were reduced. Subsequently, an increase in wave height is noticeable on the left side of the cyclone track when waves and currents opposed each other (waves propagated from southwest and currents flowed towards the southwest direction; Fig. 7). In general, wave-current interaction is prominent when currents are strong. The effect of currents on the wave field is examined by comparing the wave parameters collected off Visakhapatnam and the model results obtained from SWAN 
Table 1. Statistical measures with (coupled) and without (stand-alone) currents on waves at the buoy location.

\begin{tabular}{|c|c|c|c|c|c|}
\hline Statistical metrics & Mean (m) & Bias (m) & RMSE (m) & Scatter index & $\begin{array}{c}\text { Correlation } \\
\text { coefficient }\end{array}$ \\
\hline SWAN (stand-alone) & 1.89 & -0.08 & 0.53 & 0.28 & 0.95 \\
\hline Coupled (ADCIRC+SWAN) & 1.89 & -0.04 & 0.48 & 0.25 & 0.95 \\
\hline
\end{tabular}
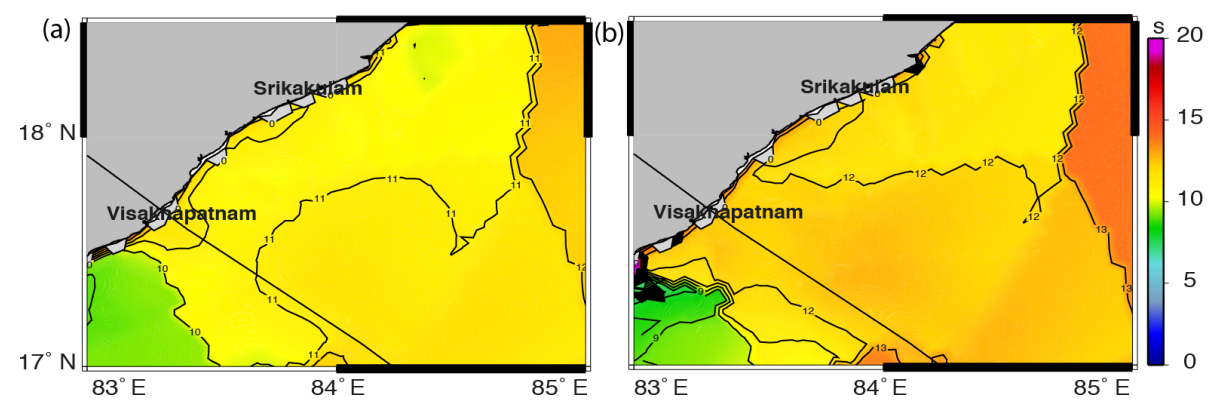

Figure 11. Spatial distribution of (a) mean wave period $\left(T_{\mathrm{m}}\right)$ and (b) peak wave period $\left(T_{\mathrm{p}}\right)$ simulated along the track of the Hudhud cyclone using coupled ADCIRC+SWAN model (with wave-current interaction).
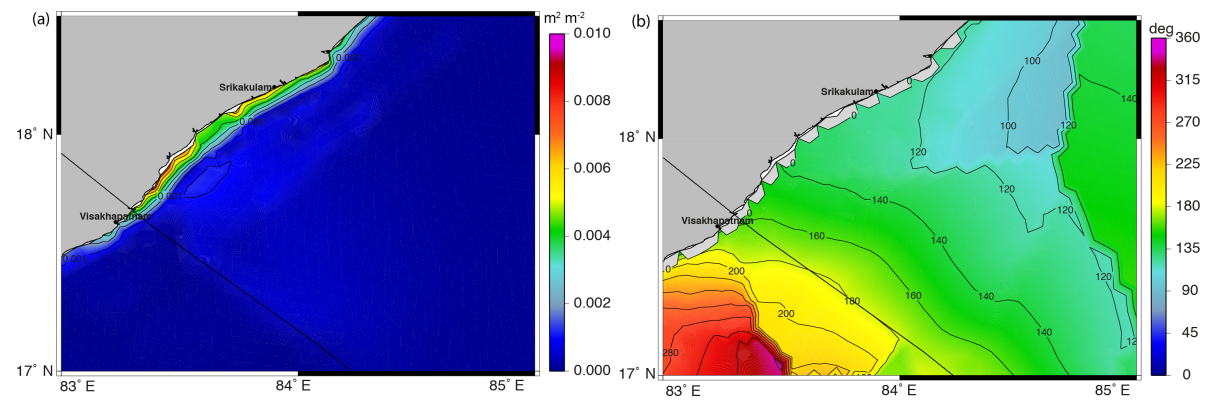

Figure 12. (a) Maximum radiation stress gradient values calculated from SWAN and (b) spatial distribution of mean wave direction simulated along the track of the Hudhud cyclone using the coupled ADCIRC+SWAN model (with wave-current interaction); colour code and contours represent wave direction.

alone and ADCIRC+SWAN just before the landfall of the cyclone (Fig. 8). As discussed earlier, we observed an increase in current speed of $\approx 1.3 \mathrm{~m} \mathrm{~s}^{-1}$ just before the landfall (Fig. 6) and an increase of $\approx 0.2 \mathrm{~m}$ in the significant wave height.

\section{Conclusions}

A coupled ADCIRC+SWAN modelling system has been used to simulate the changes that occurred in the ocean surface dynamics during the passage of the very severe cyclonic storm Hudhud that made landfall near Visakhapatnam, located on the ECI. At the time of peak intensity, the Holland parametric model reproduced maximum wind speed of $\approx 54 \mathrm{~m} \mathrm{~s}^{-1}$ with a minimum central pressure drop of $950 \mathrm{hPa}$. The landfall of Hudhud event occurred during the spring high tide and the tide gauge observation off Visakhapatnam recorded a maximum surge of $1.4 \mathrm{~m}$, which matched reasonably well with the modelled surge $(1.2 \mathrm{~m})$. The twoway coupling with SWAN showed an increment of $\approx 0.25 \mathrm{~m}$ $(20 \%)$ in the total water level elevation, which contributed through waves to the total rise in water level. During the time of landfall near Visakhapatnam, the current speed increased from 0.5 to $1.8 \mathrm{~m} \mathrm{~s}^{-1}$ for a short duration $(\approx 6 \mathrm{~h})$ with the direction of flow towards south, and thereafter $(\approx 6 \mathrm{~h})$ the current speed reduced to $\approx 0.1 \mathrm{~m} \mathrm{~s}^{-1}$ with reversal in direction (towards north). The study signifies that an increase of $\approx 0.2 \mathrm{~m}$ in significant wave height was noted when the effect of currents was included on the wave field. The inclusion of currents in the modelling system thus has influence on the wave field, especially on wave length (in the present case, a change of about $2 \mathrm{~s}$ in wave period) and wave height. Increase in wave height was observed on the left side of the cyclone track, when waves and currents opposed each other (waves were propagating from southwest and currents flowing towards southwest). As wave-current interaction is a complex problem, and the expected changes in wave parameters are 
very small, further refinement is required in the two-way coupling of ADCIRC+SWAN (with fine-resolution bathymetry and improved cyclonic winds).

Data availability. The ERA-Interim wind and wave data were freely downloaded from ECMWF (http://www.ecmwf.int/en/ research/climate-reanalysis/era-interim, Dee et al., 2011). Most of the other datasets used in the study can be requested from the corresponding author for joint research work.

Competing interests. The authors declare that they have no conflict of interest.

Acknowledgements. We thank the director of CSIR-NIO, Goa, for his support and interest in this study. The first author acknowledges the Department of Science and Technology, government of India, for supporting the research work through WOS-A(SR/WOS-A/ES17/2012). The fieldwork data sharing is bound to our institute data sharing policy. We are thankful to INCOIS, Hyderabad, for providing the wave data. We acknowledge CSIR-NIO for providing high-performance computing domain and HPC-Pravah for running the model. We are thankful to V. Surya Narayana Murty for giving input on the impact of Hudhud on the coast. We are thankful to model developers for providing the source code for the model used in this study, ADCIRC+SWAN. We are also thankful to Chaitanya for assisting in preparing the figures. We sincerely thank Ira Didenkulova, the editor and the two anonymous reviewers for their critical comments which helped us to improve this paper to a great extent. The NIO contribution number is 6122 .

Edited by: Ira Didenkulova

Reviewed by: two anonymous referees

\section{References}

Amarendra, P. G., Bharathi, P., Bhanumurthy, K., Reddy, G., and Balakrishnan Nair, T. M.: An observational study on wave characteristics during HUDHUD cyclone off Gangavaram, OSICON, CSIR, NIO, Goa 2015.

Ardhuin, F., Rascle, N., and Belibassakis, K. A.: Explicit waveaveraged primitive equations using a generalized Lagrangian mean, Ocean Model., 32, 35-60, 2008.

Atkinson, J. H., Westerink, J. J., and Hervouet, J. M.: Similarities between the Wave Equation and the Quasi-Bubble Solutions to the Shallow Water Equations, Int. J. Numer. Meth. Fl., 45, 689714, 2004

Atkinson, J. H., Westerink, J. J., Wamsley, T., Cialone, M. A., Dietrich, J. C., Dresback, K. M., Kolar, R. L., Resio, D. T., Bender, C., Blanton, B. O., Bunya, S., De Jong, W., Ebersole, B. A., Grzegorzewski, A., Jensen, R. E., Pourtaheri, H., Ratcliff, J., Roberts, H. J., Smith, J. M., and Szpilka, C. M.: Hurricane Storm Surge and Wave Modeling in Southern Louisiana: A Brief Overview, Proceedings of the Tenth International Conference on Estuarine and Coastal Modeling, 467-506, 2008.
Balakrishnan, N., Remya, P. G., Harikumar, R., Sandhya, K. G., Sirisha, P., Srinivas, K., and Nagaraju, C.: Wave forecasting and monitoring during very severe cyclone Phailin in the Bay of Bengal, Current Sci., 106, 1121-1125, 2014.

Battjes, J. A. and Janssen, J. P. F. M.: Energy loss and setup due to breaking of random waves, Proc. 16th Coastal Eng. Conf., ASCE (1978), 569-587, 1978.

Beardsley, R. C., Chen, C., and Xu, Q.: Coastal flooding in Scituate (MA): A FVCOM study of the 27 December 2010 nor'easter, J. Geophys. Res., 118, 6030-6045, https://doi.org/10.1002/2013JC008862, 2013.

Bender, F. A. M., Ramanathan, V., and Tselioudis, G.: Changes in extratropical storm track cloudiness 1983-2008: Observational support for a poleward shift, Clim. Dyn., 38, 2037-2053, https://doi.org/10.1007/s00382-011-1065-6, 2012.

Bennis, A. C., Ardhuin, F., and Dumas, F.: On the coupling of wave and three-dimensional circulation models: Choice of theoretical framework, practical implementation and adiabatic tests, Ocean Model., 40, 260-272, 2011.

Bhaskaran, P. K., Nayak, S., Bonthu, S. R., Murty, P. N., and Sen, D.: Performance and validation of a coupled parallel ADCIRCSWAN model for THANE cyclone in the Bay of Bengal, Environ. Fluid Mech., 13, 601-623, 2013.

Bhaskaran, P. K., Gayathri, R., Murty, P. L. N., Subba Reddy, B., and Sen, D.: A numerical study of coastal inundation and its validation for Thane cyclone in the Bay of Bengal, Coast. Eng., 83, 108-118, 2014.

Blain, C. A., Westerink, J. J., and Luettich, R. A.: The influence of domain size on the response characteristics of a hurricane storm surge model, J. Geophys. Res., 99, https://doi.org/10.1029/94JC01348, 1994.

Booij, N., Ris, R. C., and Holthuijsen, L. H.: A third generation wave model for coastal regions, Part I: Model description and validation, J. Geophys. Res., 104, 7649-7666, 1999.

Bunya, S., Ditriech, J. C., Westerink, J. J., Ebersole, V., Smith, J. M., Atkinson, J.,H., Jensen, R., Resio, D. T., Luettich, R. A., Dawson, C., Cardone, V. J., Cox, A. T., Powell, M. D.,Westerink, H. J., and Roberts, H. J.: A High-Resolution Coupled Riverine Flow, Tide, Wind, Wind Wave, and Storm Surge Model for Southern Louisiana and Mississippi. Part I: Model Development and Validation, Mon. Weather Rev., 138, 345-377, https://doi.org/10.1175/2009MWR2906.1, 2010.

Carniel, S. J., Chiggiato, W. J., and Sclavo, M.: Investigating the impact of surface wave breaking on modeling the trajectories of drifters in the northern Adriatic Sea during a wind-storm event, Ocean Model., 30, 225-239, 2009.

Cavaleri, L. and Malanotte-Rizzoli, P.: Wind wave prediction in shallow water: Theory and applications, J. Geophys. Res., 86, 961-973, 1981.

Davies, A. M. and Lawrence, J.: Modeling the effect of wavecurrent interaction on the three-dimensional wind-driven circulation of the eastern Irish Sea, J. Phys. Oceanogr., 25, 29-45, 2005.

Dawson, C. N., Westerink, J. J., Feyen, J. C., and Pothina, D.: Continuous, Discontinuous and Coupled Discontinuous-Continuous Galerkin Finite Element Methods for the Shallow Water Equations, Int. J. Numer. Meth. Fl., 52, 63-88, 2006.

Dee, D. P., Uppala, S. M., Simmons, A. J., Berrisford, P., Poli, P., Kobayashi, S., Andrae, U., Balmaseda, M. A., Bal- 
samo, G., Bauer, P., Bechtold, P., Beljaars, A. C. M., van de Berg, L., Bidlot, J., Bormann, N., Delsol, C., Dragani, R., Fuentes, M., Geer, A. J., Haimberger, L., Healy, S. B., Hersbach, H., Hólm, E. V., Isaksen, L., Kållberg, P., Köhler, M., Matricardi, M., McNally, A. P., Monge-Sanz, B. M., Morcrette, J.-J., Park, B.-K., Peubey, C., de Rosnay, P., Tavolato, C., Thépaut, J.-N., and Vitart, F.: The ERA-Interim reanalysis: configuration and performance of the data assimilation system, Q. J. Roy. Meteorol. Soc., 137, 553-597, https://doi.org/10.1002/qj.828, 2011 (data available at: http:// www.ecmwf.int/en/research/climate-reanalysis/era-interim, last access: October 2015).

Dhana Lakshmi, D., Murty, P. L. N., Bhaskaran, P. K., Sahoo, B., Srinivasa Kumar, T., Shenoi, S. S. C., and Srikanth, A. S.: Performance of WRF-ARW winds on computed storm surge using hydrodynamic model for Phailin and Hudhud cyclones, Ocean Eng., 131, 135-148, 2017.

Dietrich, J. C., Bunya, S., Westerink, J. J., Ebersole, B. A., Smith, J. M., Atkinson, J. H., and Jensen, R.: A high-resolution coupled riverine flow, tide, wind, wind wave, and storm surge model for southern Louisiana and Mississippi. Part II: Synoptic description and analysis of Hurricanes Katrina and Rita, Mon. Weather Rev., 138, 378-404, 2010.

Dietrich, J. C., Westerink, J. J., Kennedy, A. B., Smith, J. M., Jensen, R. E., Zijlema, M., and Holthuijsen, L. H.: Hurricane Gustav (2008) waves and storm surge: Hindcast, synoptic analysis, and validation in southern Louisiana, Mon. Weather Rev., 139, 2488-2522, 2011a.

Dietrich, J. C., Zijlema, M., Westerink, J. J., Holthuijsen, L. H., Dawson, C., Luettich, R. A., Jensen, R. E., Smith, J. M., Stelling, G. S., and Stone, G. W.: Modeling hurricane waves and storm surge using integrally-coupled, scalable computations, Coast. Eng., 58, 45-65, $2011 \mathrm{~b}$.

Dietrich, J. C., Tanaka, S., Westerink, J. J., Dawson, C. N., Luettich Jr., R. A., Zijlema, M., Holthuijsen, L. H., Smith, J. M., Westerink, L. G., Westerink, H. J.: Performance of the unstructuredmesh, SWAN+ ADCIRC model in computing hurricane waves and surge, J. Sci. Comput., 52, 468-497, 2012.

Dietrich, J. C., Dawson, C. N., Proft, J. M., Howard, M. T., Wells, G., Fleming, J. G., Luettich Jr., R. A., Westerink, J. J., Cobell, Z., Vitse, M., Lander, H., Blanton, B. O., Szpilka, C. M., and Atkinson, J. H.: Real-Time Forecasting and Visualization of Hurricane Waves and Storm Surge Using SWAN+ADCIRC and FigureGen, Computational Challenges in the Geosciences, The IMA Volumes in Mathematics and its Applications, 156, 49-70, https://doi.org/10.1007/978-1-4614-7434-0_3, 2013.

Dong, Z. and Kirby, T.: Theoretical and numerical study of wavecurrent interaction in strongly-sheared flows, Coast Eng. Proc., 1, 1-7, 2012.

Dube, S. K., Rao, A. D., Sinha, P. C., Murty, T. S., and Bahulayan, N.: Storm surge in the Bay of Bengal and Arabian Sea: the problem and its prediction, Mausam., 48, 283-230, 1997.

Dube, S. K., Chittibabu, P., Rao, A. D., Sinha, P. C., and Murty, T. S.: Extreme sea levels associated with severe tropical cyclones hitting Orissa coast of India, Marine Geodesy, 23, 75-90, 2000.

Eldeberky, Y., Polnikov, V., and Battjes, J. A.: A statistical approach for modeling triad interactions in dispersive waves, Proc. 25th Int. Conf. Coastal Eng., 1088-1101, 1996.
Hani, T., Ganesan, P., and Murty, V. S. N.: Impact of the very severe cyclonic storms - The Phailin and Hudhud - on the beach processes along the Visakhapatnam coast, OSICON, CSIR,NIO, Goa, 2015.

Hasselmann, K., Barnett, T. P., Bouws, E., Carlson, H., Cartwright, D. E., Enke, K., Ewing, J. A., Gienapp, H., Hasselmann, D. E., Kruseman, P., Meerburg, A., Mller, P., Olbers, D. J., Richter, K., Sell, W., and Walden, H.: Measurements of wind-wave growth and swell decay during the Joint North Sea Wave Project (JONSWAP), Ergnzungsheft zur Deutschen Hydro. Zeitschrift Reihe, A(8) (Nr. 12), p. 95, 1973.

Hasselmann, S., Hasselmann, K., Allender, J., and Barnett, T.: Computations and parameterizations of the nonlinear energy transfer in a gravity-wave specturm. Part II: Parameterizations of the nonlinear energy transfer for application in wave models, J. Phys. Oceanogr., 15, 1378-1391, 1985.

Holland, G. J.: An analytic model of the wind and pressure profiles in hurricanes, Mon. Weather Rev., 108, 1212-1218, 1980.

Holthuijsen, L. H. and Tolman, H. L.: Effects of the Gulf Stream on ocean waves, J. Geophys. Res., 96, 12755-12771, https://doi.org/10.1029/91JC00901, 1991.

Hope, M. E., Westerink, J. J., Kennedy, A. B., Kerr, P. C., Dietrich, J. C., Dawson, C., and Bender, C. J.: Hindcast and validation of Hurricane Ike (2008) waves, forerunner, and storm surge, J. Geophys. Res., 118, 4424-4460, 2013.

Garrett, C.: Generation of Langmuir circulations by surface waves -a feedback mechanism, J. Mar. Res., 34, 117-130, 1976.

Gayathri, R., Bhaskaran, P. K., and Sen, D.: Numerical study on Storm Surge and associated Coastal Inundation for 2009 AILA Cyclone in the head Bay of Bengal. Int. Conf. on Water Resources, Coastal and Ocean Engineering (ICWRCOE 2015), Aquatic Procedia, 4, 404-411, 2015.

Gayathri, R., Murty, P. L. N., Bhaskaran, P. K., and Srinivasa Kumar, T.: A numerical study of hypothetical storm surge and coastal inundation for AILA cyclone in the Bay of Bengal, Environ. Fluid Mech., 16, 429-452, 2016.

Gayathri, R., Bhaskaran, P. K., and Jose, F.: Coastal inundation research: an overview of the process, Current Science, 112, 267278, 2017.

IMD Report: Very Severe Cyclonic Storm, HUDHUD over the Bay of Bengal (7-14 October 2014), A Report, 2014.

Kirby, J. T. and Tsung-Muh, C.: Surface waves on vertically sheared flows: approximate dispersion relations, J. Geophys. Res.-Oceans, 94, 1013-1027, 1989.

Kolar, R. L., Westerink, J. J., Cantekin, M. E., and Blain, C. A.: Aspects of nonlinear simulations using shallow water models based on the wave continuity equation, Comput. Fluids, 23, 523538, 1994.

Komen, G., Hasselmann, K., and Hasselmann, S.: On the existence of a fully developed wind-sea spectrum, J. Phys. Oceanogr., 14, 1271-1285, 1984.

Komen, G. J., Cavaleri, L., Donelan, M., Hasselmann, K., Hasselmann, S., and Janssen P. A. E. M.: Dynamics and Modelling of Ocean Waves, 532 pp., Cambridge Univ. Press, New York, 1994.

Kubatko, E. J., Bunya, S., Dawson, C., and Westerink, J. J.: Dynamic p-adaptive Runge-Kutta Discontinuous Galerkin Methods for the Shallow Water Equations, Computer Methods in Applied Mechanics and Engineering, 198, 1766-1774, 2009. 
Kudryavtsev, V. N., Makin, V. K., and Chapron, B.: Coupled Sea Surface-Atmosphere Model 2. Spectrum of Short Wind Waves, J. Geophys. Res., 104, 7625-7639, 1999.

Kuik, A. J., Vledder, G., and Holthuijsen, L. H.: A method for the routine analysis of pitch and roll buoy wave data, J. Phys. Oceanogr., 18, 1020-1034, 1988.

Liu, Z., Lin, Z., Tao, L., and Lan, J.: Nonlinear Wave-Current Interaction in Water of Finite Depth. Journal of Waterway, Port, Coastal, Ocean Eng., 142, 04016009, 1-16, 2016.

Longley, K. E.: Wave Current Interactions and Wave-blocking Predictions Using NHwave model, MSc dissertation, Naval postgraduate school Monterey CA, 2013.

Longuet-Higgins, M. S. and Stewart, R. W.: Radiation stresses in water waves; a physical discussion, with application, Deep-Sea Res., 11, 529-562, 1964.

Luettich, R. A. and Westerink, J. J.: Continental shelf scale convergence studies with a barotropic tidal model, Quantitative skill assessment for coastal ocean models, 349-371, 1995.

Luettich, R. A. and Westerink, J. J.: Formulation and numerical implementation of the 2D/3D ADCIRC finite element model version 44, Tech Rep., 2004.

Mastenbroek, C., Burgers, G., and Janssen, P. A. E. M.: The dynamical coupling of a wave model and a storm surge model through the atmospheric boundary layer, J. Phys. Oceanogr., 23, 1856$1866,1993$.

McWilliams, J. C., Restrepo, J. M., and Lane, E. M.: An asymptotic theory for the interaction of waves and currents in coastal waters, J. Fluid Mech., 511, 135-178, https://doi.org/10.1017/S0022112004009358, 2004.

Mellor, G. L.: The three-dimensional current and surface wave equations, J. Phys. Oceanogr., 33, 1978-1989, 2003.

Mellor, G. L.: The depth-dependent current and wave interaction equations: a revision, J. Phys. Oceanogr., 38, 2587-2596, 2008.

Mishra, P., Patra, S. K., Bramha, S., Mohanty, P. K., Panda, U. S., Rao, V. R., and Ramanamurthy, M. V.: Wave characteristic and tidal regime off Gopalpur, east coast of India and its implication in coastal erosion, in: Proceedings of the joint Indo-Brazil workshop on coastal process and modeling relevant to understanding shoreline changes, Chennai, India, 22-32 4, 2010.

Misra, S. K., Chandramohan, P., Satyanarayana, M. A., Panigrahi, J. K., and Mahadevan, R.: Nature of the tide induced flow field along the East Coast of India, Int. J. Oceans Oceanogr., 7, 57-71, 2013

Moon, Il-J.: Impact of a coupled ocean wave-tide-circulation system on coastal modeling, Ocean Model., 8, 203-236, 2005.

Murty, P. L. N., Sandhya, K. G., Bhaskaran, P. K., Felix, J., Gayathri, R., Balakrishnan, N. T. M., SrinivasaKumar, T., and Shenoi, S. S.: A coupled hydrodynamic modeling system for PHAILIN cyclone in the Bay of Bengal, Coast. Eng., 93, 71-81, 2014.

Murty, P. L. N., Bhaskaran, P. K., Gayathri, R., Sahoo, B., Srinivasa Kumar, T., and SubbaReddy, B.: Numerical study of coastal hydrodynamics using a coupled model for Hudhud cyclone in the Bay of Bengal, Estuar. Coast. Shelf Sci., 183, 13-27, 2016.

Murty, T. S., Flather, R. A., and Henry, R. F.: The storm surge problem in the Bay of Bengal, Prog. Oceanogr., 16, 195-233, 1986.

Panigrahi, J. K. and Swain, J.: Numerical Simulation and Validation of Deepwater Spectral Wind-Waves, Marine Geodesy., 33, 39$52,2010$.
Pleskachevsky, A., Eppel, D. P., and Kapitza, H.: Interaction of waves, currents and tides, and wave-energy impact on the beach area of Sylt Island, Ocean Dynam., 59, 451-461, 2009.

Poulose, J., Rao, A. D., and Bhaskaran, P. K.: Role of continental shelf on non-linear interaction of storm surges, tides and wind waves: An idealized study representing the west coast of India. Estuarine, Coast. Shelf Sci. https://doi.org/10.1016/j.ecss.2017.06.007, 2017.

Rao, A. D.: Numerical storm surge prediction in India, Ph.D. thesis, IIT Delhi, New Delhi, 211 pp., 1982.

Rao, A. D., Murty, P. L. N., Jain, I., Kankara, R. S., Dube, S. K., and Murty, T. S.: Simulation of water levels and extent of coastal inundation due to a cyclonic storm along the east coast of India, Nat. Hazards, 66, 1431-1441, https://doi.org/10.1007/s 11069012- 0193-6, 2013a.

Rao, V. R., Subramanian, B. R., Mohan, R., Kannan, R., Mageswaran, T., Arumugam, T., and Rajan, B.: Storm surge vulnerability along Chennai-Cuddalore coast due to severe cyclone THANE, Nat. Hazards, 68, 453-465, https://doi.org/10.1007/s11069-013-0630-1, 2013b.

Ris, R., Holthuijsen, L. H., and Booij, N.: A third-generation wave model for coastal regions: 2. Verification, J. Geophys. Res., 104, 7667-7681, 1999.

Schott, F. A. and McCreary, J. P.: The monsoon circulation in the Indian Ocean, Prog. Oceanogr., 51, 1-123, doi:10.1016/S0079. 6611(01)00083-0, 2001.

Schott, F., Reppin, J., Fischer, J., and Quadfasel, D.: Currents and transports of the Monsoon Current south of Sri Lanka, J. Geophys. Res., 99, https://doi.org/10.1029/94JC02216, 1994.

Sebastian, A., Bedient, P., Proft, J., Dietrich, J., and Dawson, C.: Characterizing hurricane storm surge behavior in Galveston Bay using the SWAN+ADCIRC Model, Coast. Eng., 88, 171-181, https://doi.org/10.1016/j.coastaleng.2014.03.002, 2014.

Shankar, D., Vinayachandran, P. N., and Unnikrishnan, A. S.: The monsoon currents in the north Indian Ocean, Progr. Oceanogr. 52, 63-120, 2002.

Sindhu, B., Suresh, I., Unnikrishnan, A. S., Bhatkar, N. V., Neetu, S., and Michael, G. S.: Improved bathymetric datasets for the shallow water regions in the Indian Ocean, J. Earth Syst. Sci., 166, 261-274, 2007.

Tanaka, S., Bunya, S., Westerink, J. J., Dawson, C., and Luettich, R. A.: Scalability of an Unstructured Grid Continuous Galerkin Based Hurricane Storm Surge Model, J. Sci. Comput., 46, 329358, 2011.

Tolman, H. L.: A third-generation model for wind waves on slowly varying, unsteady, and inhomogeneous depths and currents, J. Phys. Oceanogr., 21, 782-797, 1991.

Uchiyama, Y., McWilliams, J. C., and Shchepetkin, A. F.: Wavecurrent interaction in an oceanic circulation model with a vortexforce formalism: application to the surf zone, Ocean Model., 34, 16-35, 2010.

Warner, J. C., Sherwood, C. R., Signell, R. P., Harris, C. K., and Arango, H. G.: Development of a three-dimensional, regional, coupled wave, current, and sediment-transport model, Comput. Geosci., 34, 1284-1306, 2008.

Westerink, J. J., Luettich, R. A., Feyen, J. C., Atkinson, J. H., Dawson, C., Hugh, J. R., Powell, M. D., Dunion, J. P., Kubatko, E. J., and Pourtaheri, H.: A basin-to channel-scale unstructured grid 
hurricane storm surge model applied to southern Louisiana, Mon. Weather Rev., 136, 833-864, 2008.

Xia, Y., Yang, Z., Jackson, C., Stoffa, P. L., and Sen, M. K.: Impacts of data length on optimal parameter and uncertainty estimation of a land surface model, J. Geophys. Res., 109, D07101, https://doi.org/10.1029/2003JD004419, 2004.

Xie, L., Wu, K., Pietrafesa, L., and Zhang, C.: A numerical study of wave-current interaction through surface and bottom stresses: Wind-driven circulation in the South Atlantic Bight under uniform winds, J. Geophys. Res., 106, 16841-16855, 2001.

Xie, L., Pietrafesa, L. J., and Wu, K.: A numerical study of wavecurrent interaction through surface and bottom stresses: Coastal ocean response to Hurricane Fran of 1996, J. Geophys. Res., 108, 3049, https://doi.org/10.1029/2001JC001078, 2003.
Zhang, M., Zhao, Y. W., Chen, H., and Jiang, W. Q.: SAR imaging simulation for composite model of ship on dynamic ocean scene, Progress In Electromagnetics Research, 113, 395-412, 2011.

Zhang, M. Y. and Li, Y. S.: The synchronous coupling of a third-generation wave model and a two-dimensional storm surge model, Ocean Eng., 23, 533-543, 1996.

Zijlema, M.: Computation of wind-wave spectra in coastal waters with SWAN on unstructured grids, Coast. Eng., 57, 267-277, 2010. 